\title{
Ewidencjonowany niepaństwowy zasób archiwalny - wprowadzenie do problemu
}

ZARYS TREŚcI: Artykuł podejmuje temat ewidencjonowanego niepaństwowego zasobu archiwalnego, który stanowi jedną z części narodowego zasobu archiwalnego, jednak należące do niego materiały archiwalne znajdują się głównie w rękach podmiotów prywatnych, niezaliczanych do sektora publicznego. Dokonano podsumowania interpretacji prawnej zagadnienia, przede wszystkim prawnego umocowania relacji miedzy państwową administracją archiwalną a właścicielami niepaństwowego zasobu archiwalnego i ich archiwami oraz archiwami społecznymi.

sŁowA KLUCzowe: narodowy zasób archiwalny, niepaństwowy zasób archiwalny, ustawa archiwalna, archiwum społeczne, organizacja pozarządowa

AвSTRACT: The article discusses the subject of registered non-state archival collection which constitutes one of the parts of national archival collections; however the non-state archival materials are mainly in possession of private entities, not classified as part the public sector. The study recapitulates the legal interpretation of the issue, first of all the legal status of relations between the state archival administration and the owners of non-state archival collections as well as their archives and social archives.

KEYWORDS: national archival collection, non-state archival collection, Archival Act, social archives, non-governmental organization 
Podstawowym założeniem poniższych rozważań jest prześledzenie stanu prawnego i rzeczywistego stanu ewidencjonowanego niepaństwowego zasobu archiwalnego, ze zwróceniem uwagi na możliwości rozwiązania wynikających z nich problemów.

Poza częścią w prowadzającą ukazującą stan prawny w kontekście historycznym, odpowiedzialność służby archiwalnej, zasadniczą część opracowania stanowić będzie omówienie problemów w systemie kształtowania zasobu, potrzeb i propozycji jego zmian. Autor postara się odpowiedzieć na pytania: Czy nie należy przywrócić prowadzenia rejestru niepaństwowego zasobu? Czy ustanowienie monopolu archiwów państwowych na gromadzenie archiwaliów wytworzonych przez instytucje prywatne rzeczywiście jest najlepszym sposobem zabezpieczenia ich spuścizny dokumentacyjnej wobec potencjału bibliotek lub archiwów społecznych? Czy relatywnie większa rola innych regulacji niż ustawa archiwalna, np. przepisy o ochronie danych osobowych lub w pewnych sytuacjach prawo o dostępie do informacji publicznej, nie wpływa ujemnie na proces udostępniania materiałów?

Oprócz próby odpowiedzi na powyższe pytania, w artykule zasugerowane zostaną propozycje zmian w opiece nad archiwaliami z niepaństwowego zasobu, a na przykładzie wybranych aspektów z działalności Fundacji Ośrodka KARTA Autor postara się ukazać, jak archiwa niepaństwowe wyręczają państwo polskie w opiece nad archiwaliami.

Pojęcie narodowego zasobu archiwalnego, jako nadrzędnego wobec obu poniższych, do archiwistyki polskiej wprowadziła dopiero ustawa o narodowym zasobie archiwalnym i archiwach z 1983 r. Ponadto Sejm PRL, poza pojęciem „państwowy zasób archiwalny", zdefiniował nowy, osobny konstrukt prawny i element archiwalnej rzeczywistości - „niepaństwowy zasób archiwalny” i określił w ten sposób podstawę podziału narodowego zasobu archiwalnego, ze względu na stosunek własności materiałów archiwalnych, na dwie wyodrębnione w ustawie kategorie ${ }^{1}$.

Ewidencjonowany niepaństwowy zasób archiwalny stanowi jedną z części narodowego zasobu archiwalnego, który obejmuje wszystkie materiały archiwalne znajdujące się na terenie kraju, bez względu na tytuł własności do nich, oraz te, które na mocy prawa lub zwyczajów międzynarodowych przynależą do Polski. Narodowy zasób archiwalny dzieli się na państwowy oraz niepaństwowy. Konsekwencją podziału narodowego zasobu na dwa elementy jest odrębny status prawny każdego z nich.

${ }^{1}$ M. Konstankiewicz, A. Niewęgłowski, Narodowy zasób archiwalny i archiwa. Komentarz, Warszawa 2016, s. 37. 
Państwowy zasób archiwalny narasta w instytucjach państwowych i samorządowych i jest własnością państwa. Drugim elementem składowym narodowego zasobu archiwalnego jest zasób niepaństwowy, którego formalnymi właścicielami są jednostki niepaństwowe. Zasób niepaństwowy rozdzielony został według kryterium podmiotowego na ewidencjonowany i nieewidencjonowany ${ }^{2}$. Zasobem ewidencjonowanym niepaństwowym zwykło się nazywać tę część dokumentacji, która przechowywana jest w instytucjach niepaństwowych takich jak partie polityczne, stowarzyszenia, kościoły itp., zaś zasób nieewidencjonowany znajduje się już wyłącznie w rękach prywatnych. Jednak samo prawo nie jest tu dostatecznie ścisłe, ponieważ np. stowarzyszenia, które określić należy jako instytucje niepaństwowe, znajdują się zarazem w prywatnej dyspozycji.

Dokumentacja prywatna wchodząca w skład narodowego zasobu archiwalnego podlega ochronie jako dobra kultury. Wspólnie tworzą one dokumentację zakwalifikowaną do wieczystego przechowywania w archiwach.

Obowiązujące przed wybuchem II wojny światowej prawo archiwalne zakładało ograniczoną ingerencję archiwów państwowych w działalność archiwów niepaństwowych oraz gwarantowało ich niezależność. Prawo zakładało również, że materiały archiwalne pełnią ważną rolę także w działalności podmiotów niepaństwowych. W założeniu państwowej służby archiwalnej działalność tej pierwszej miała uzupełniać duża liczba archiwów niepaństwowych, a zadaniem państwowej służby archiwalnej powinna być wyłącznie opieka nad materiałami archiwalnymi tworzonymi przez instytucje państwowe, naczelne władze państwowe i administrację rządową ${ }^{3}$.

Dekret z 1919 r. o organizacji archiwów państwowych i opiece nad archiwaliami zakładał m.in. upodmiotowienie obywateli i organizacji pozarządowych w zakresie organizowania oraz prowadzenia archiwów, poszanowanie ich prawa własności ${ }^{4}$. Państwowa służba archiwalna gromadziła i przechowywała prawie wyłącznie akta władz, administracji i instytucji państwowych, które z punktu widzenia interesów państwa polskiego tworzyły materiały archiwalne o wartości historycznej. Pozostałe materiały archiwalne miały gromadzić i przechowywać insty tucje prywatne i osoby prywatne - właściciele zbiorów archiwalnych (archiwaliów) - np. samorządy

${ }^{2}$ Ibidem, s. 43-44.

${ }^{3}$ R. Galuba, Archiwa organizacji pozarzadowych w polskim prawie archiwalnym 1918-2012, [w:] Archiwa organizacji pozarzadowych w Polsce, red. T. Czarnota, M. Konstankiewicz, Lublin 2015, s. 29-30.

${ }^{4}$ Dekret z dnia 7 lutego 1919 r. o organizacji archiwów państwowych i opiece nad archiwaljami (Dz.Pr.P.P. $1919 \mathrm{nr} 14$ poz. 182). 
terytorialne, przedsiębiorstwa przemysłowe i handlowe, organizacje społeczne, polityczne, fundacje, związki wyznaniowe i osoby prywatne ${ }^{5}$.

Diametralnie inna sytuacja zapanowała po 1944 r., kiedy powszechne stało się bagatelizowanie przez państwowych i niepaństwowych twórców materiałów archiwalnych przepisów dotyczących działalności archiwalnej. Lekceważenie prawa naraziło znaczną część materiałów archiwalnych na zniszczenie, a procedura brakowania akt była uważana przez podmioty państwowe i niepaństwowe za skomplikowaną, czasochłonną i zbędną. W dodatku Rada Ministrów nie przewidziała żadnych sankcji wobec podmiotów, także niepaństwowych, za brakowanie materiałów archiwalnych kategorii B bez zgody właściwego archiwum państwowego lub bezprawne niszczenie materiałów archiwalnych kategorii A i B. Dekretem z 1951 r. ${ }^{6}$ wprawdzie przyznano archiwom państwowym szerokie uprawnienia w zakresie zabezpieczania narastającego zasobu archiwalnego, jednak z wyłączeniem innych organizacji, które nie tworzyły państwowego zasobu archiwalnego. Wynikiem zmian gospodarczych i wyraźnej dominacji państwa w życiu społecznym, kulturalnym i naukowym było dużo większe niż w II Rzeczypospolitej upaństwowienie podmiotów gospodarczych? ${ }^{7}$.

Wiodące po dziś dzień znaczenie dla prawnych podstaw działalności archiwalnej w ówczesnej Polsce ma Ustawa z 14 lipca 1983 r. o narodowym zasobie archiwalnym i archiwach, dalej określana jako ustawa archiwalna (Dz.U. 2020, poz. 164). Ustawa weszła w życie 1 stycznia 1984 r., później poddana została licznym, lecz fragmentarycznym zmianom. Wielokrotnie modyfikowano przepisy dotyczące ustroju archiwów, kształtowania narastającego państwowego zasobu archiwalnego i jego udostępniania, a nieco rzadziej statusu niepaństwowego zasobu archiwalnego ${ }^{8}$. Przepisy ustawy archiwalnej tworzą formalne fundamenty działania archiwów, w tym administracji archiwalnej, czyli Naczelnego Dyrektora Archiwów Państwowych oraz dyrektorów archiwów państwowych?.

${ }^{5}$ R. Galuba, op. cit., s. 30.

${ }^{6}$ Dekret z dnia 29 marca 1951 r. o archiwach państwowych (Dz.U. $1951 \mathrm{nr} 19$ poz. 149).

${ }^{7}$ R. Galuba, op. cit., 34.

${ }^{8}$ M. Konstankiewicz, Kształtowanie podstaw prawnych działalności archiwalnej w Polsce na przełomie XX i XXI wieku, „Archeion”, t. 120, 2019, s. 359.

${ }^{9}$ Ustawa z dnia 14 lipca 1983 r. o narodowym zasobie archiwalnym i archiwach (Dz.U. z 2019 r. poz. 553). Obwieszczenie Marszałka Sejmu Rzeczypospolitej Polskiej z dnia 13 grudnia 2019 r. w sprawie ogłoszenia jednolitego tekstu ustawy o narodowym zasobie archiwalnym i archiwach. Załącznik do obwieszczenia Marszałka Sejmu Rzeczypospolitej Polskiej z dnia 13 grudnia 2019 r. (Dz.U. 2020 poz. 164). 
Na mocy ustawy zaczął obowiązywać podział narodowego zasobu archiwalnego używający kryterium własnościowego. W skład narodowego zasobu archiwalnego zalicza się państwowy zasób archiwalny, czyli materiały wchodzące do niego z mocy prawa i materiały nabyte przez Skarb Państwa, jednostki samorządu terytorialnego, jednostki państwowe, samorządowe i osoby prawne, oraz niepaństwowy zasób archiwalny. Sam niepaństwowy zasób archiwalny, który tworzą materiały archiwalne niewchodzące do państwowego zasobu archiwalnego, dzieli się na ewidencjonowany i nieewidencjonowany. Interesujący nas ewidencjonowany niepaństwowy zasób archiwalny tworzony jest przez materiały archiwalne powstałe ${ }^{10}$ i powstające w wyniku działalności partii politycznych, organizacji politycznych, spółdzielczych i innych organizacji społecznych, Kościołów i związków wyznaniowych, innych niż wymienione niepaństwowych jednostek organizacyjnych oraz stanowiące ich własność ${ }^{11}$. Niepaństwowy zasób, niejako przeciwieństwo państwowego, jest w istocie swoistą zbiorowością zasobów poszczególnych właścicieli archiwaliów, czyli prywatnym zasobem.

Składnikiem niepaństwowego ewidencjonowanego zasobu archiwalnego są zatem materiały archiwalne wytworzone przez różnorakie instytucje: w szczególności przez Kościoły i kościelne osoby prawne (które mają prawo do zakładania i posiadania archiwum), i związki wyznaniowe. Kościół rzymskokatolicki posiada w Polsce rozwiniętą sieć archiwów diecezjalnych zawierających cenne archiwalia pomocne do odtworzenia historii nie tylko instytucji kościelnych ${ }^{12}$. Ponadto ewidencjonowany niepaństwowy zasób archiwalny tworzą także spółdzielnie, spółki handlowe, kapitałowe, partie polityczne, stowarzyszenia czy przedsiębiorstwa, organizacje społeczne (korporacje) - związki zawodowe i inne, np. fundacje czy kluby sportowe. Przy tym niektórym z nich (szczególnie partiom politycznym i związkom zawodowym) z racji ich pozycji ustrojowej blisko, co podkreśla się w literaturze, do instytucji publicznych z państwowego zasobu archiwalnego ${ }^{13}$.

10 Użyte sformułowanie „powstałe” należało jednak objaśnić, gdyż zgodnie z art. 15 ust. 2 ustawy z 1983 r. archiwalia wytworzone przez owe podmioty także tworzą państwowy zasób archiwalny, jeżeli (pkt 5) „materiały te stały się własnością Państwa w wyniku zakupu, darowizny lub w innej drodze".

11 Rozdział 4 Ustawy archiwalnej, art. 41 i art. 42 (Dz.U. 2020 poz. 164).

12 P. Wolnicki, Podstawy współpracy państwowej służby archiwalnej w Polsce z Kościołami i związkami wyznaniowymi, „Archeion”, t. 115, 2014, s. 153-166.

13 W. Stępniak, Czy wiemy, czym jest instytucja narodowego zasobu archiwalnego?, [w:] Zatrzymać przeszłość, dogonić przyszłość. Pamiętnik VI Powszechnego Zjazdu Archiwistów Polskich. Wrocław, 5-7 września 2012 r., red. W. Chorążyczewski, K. Stryjkowski, Warszawa 2013, s. 12; T. Czarnota, Problematyka działalności dokumentacyjnej współczesnych archiwów, [w:] Toruńskie 
Archiwalia powstają również w wyniku działalności tak instytucji polonijnych oraz archiwów zagranicznych, w których przechowywane są polskie materiały archiwalne, a także osób prawnych i jednostek organizacyjnych nieposiadających osobowości prawnej, wymienionych $\mathrm{w}$ art. 42 ustawy archiwalnej, jak i rodzin i osób fizycznych, które tworzą i gromadzą materiały (spuścizny itp.) - zaliczone w art. 46 ustawy do nieewidencjonowanego niepaństwowego zasobu archiwalnego.

Znaczącą zmianą wpływającą na niepaństwowy zasób archiwalny była ustawa z 18 października 2006 r. o zmianie i uchyleniu niektórych upoważnień do wydawania aktów wykonawczych (Dz.U. 2006, nr 220, poz. 1600). Zlikwidowano możliwość wypłacania ekwiwalentu za nakłady związane z przechowywaniem, zabezpieczeniem i konserwacją materiałów archiwalnych wchodzących do niepaństwowego zasobu archiwalnego, w razie ich przekazania właściwym jednostkom państwowej sieci archiwalnej.

Najbardziej rozległa była nowelizacja z 2 marca 2007 r. Objęła ona m.in. zmiany w przepisach o ochronie archiwaliów, określające status większości kategorii podmiotów prowadzących działalność w zakresie państwowego zasobu archiwalnego, udostępniania tego zasobu oraz oddziaływania administracji archiwalnej na niepaństwowy zasób archiwalny ${ }^{14}$. Zlikwidowano instytucję rejestru niepaństwowego zasobu archiwalnego oraz wprowadzono instytucję przymusowego przejęcia na przechowanie $\mathrm{w}$ archiwum państwowym materiałów archiwalnych w razie ich zagrożenia.

Wnioski z posiedzenia Sejmowej Komisji Kultury i Środków Przekazu, poświęconej sytuacji narodowego zasobu archiwalnego, wskazują, że wprowadzenie ewidencjonowanego niepaństwowego zasobu archiwalnego z perspektywy czasu należy ocenić wysoko. Instytucja ta nabrała szczególnego znaczenia w nowej rzeczywistości prawnej i społecznej, jaka kształtuje się od 1989 r. „W kraju demokratycznym konieczne jest poszanowanie niezależności instytucji życia publicznego, takich jak partie polityczne, związki zawodowe, fundacje i stowarzyszenia, kościoły czy też prywatne podmioty sfery życia gospodarczego" ${ }^{\text {15 }}$.

\footnotetext{
konfrontacje archiwalne, t. 4, Nowa archiwistyka - archiwa i archiwistyka w ponowoczesnym kontekście kulturowym, red. W. Chorążyczewski, W. Piasek, A. Rosa, Toruń 2014, s. 65, 69.

${ }^{14}$ Ustawa $\mathrm{z}$ dnia 2 marca 2007 r. o zmianie ustawy o narodowym zasobie archiwalnym i archiwach oraz ustawy - Kodeks pracy (Dz.U. 2007, nr 64, poz. 426).

${ }^{15}$ Kancelaria Sejmu Biuro Komisji Sejmowych. Pełny zapis przebiegu posiedzenia Komisji Kultury i Środków Przekazu (nr 15) z dnia 29 lutego 2012 r. Sytuacja narodowego zasobu archiwalnego i archiwów państwowych. Informacja dla Sejmowej Komisji Kultury i Środków Przekazu, $<$ https://www.archiwa.gov.pl/>, [dostęp 16.09.2020].
} 
W roku 2015 wprowadzono mechanizm wspierania działalności archiwalnej organizacji pozarządowych oraz zmodyfikowano zasady przejmowania archiwaliów z niepaństwowych jednostek organizacyjnych do archiwów państwowych ${ }^{16}$. Wprowadzono również dyrektywy dotyczące współpracy archiwów państwowych z podmiotami prywatnymi, których materiały archiwalne wchodzą w skład ewidencjonowanego niepaństwowego zasobu archiwalnego ${ }^{17}$.

Zgodnie z obecnymi przepisami każdego roku dyrektorzy archiwów państwowych, kierując się wytycznymi, przeprowadzają rozpoznanie liczby i rodzajów podmiotów, z którymi wskazane jest kontynuowanie lub nawiązanie współpracy ${ }^{18}$. Wycinkowa analiza rocznych sprawozdań dyrektorów AP pod kątem uchwycenia tego, jak udaje im się realizować tę współpracę, nie daje jednak jednoznacznych wyników ${ }^{19}$. W sprawozdaniach dyrektorów można znaleźć lapidarne informacje o zaopiniowaniu przez Komisję Archiwalnej Oceny Dokumentacji (KAOD) wykazu podmiotów wytwarzających materiały archiwalne, wchodzących w skład niepaństwowego zasobu, a mających siedzibę w granicach właściwości miejscowej archiwum, lecz trudno znaleźć konkretne liczby czy przykłady ulokowanych w nim podmiotów.

Dzieląc obszar oddziaływania państwa na aktotwórców z ewidencjonowanego niepaństwowego zasobu archiwalnego, należy, wg T. Czarnoty, wyróżnić grupy, które przybierają formy bezpośredniego i pośredniego wpływu. W ramach bezpośredniego oddziaływania państwa wydzielić można następujące obszary problemowe, tj.: a) kontrolowanie sposobu postępowania $\mathrm{z}$ archiwaliami; b) podejmowanie działań zabezpieczających archiwalia (zwłaszcza zagrożone destrukcją) $\mathrm{w}$ formie przymusowych lub dobrowolnych czasowych depozytów w zasobie archiwum państwowego; c) przyjmowanie do zasobu archiwum dokumentacji

${ }^{16}$ Ustawa z dnia 20 marca $2015 \mathrm{r}$. o zmianie ustawy o narodowym zasobie archiwalnym i archiwach (Dz.U. 2015, poz. 566) i Rozporządzenie Ministra Kultury i Dziedzictwa Narodowego z dnia 14 października 2015 r. w sprawie warunków i trybu przekazywania do archiwów państwowych materiałów archiwalnych tworzących ewidencjonowany niepaństwowy zasób archiwalny (Dz.U. 2015, poz. 1733).

17 Zarządzenie Nr 39 Naczelnego Dyrektora Archiwów Państwowych z dnia 26 kwietnia 2018 r. w sprawie współpracy archiwów państwowych z podmiotami, których materiały archiwalne wchodzą w skład ewidencjonowanego niepaństwowego zasobu archiwalnego (znoszące Zarządzenie $\mathrm{Nr} 16 \mathrm{z} 10$ grudnia 2012 r.).

${ }_{18}$ W. Stępniak, Czy wiemy, czym jest instytucja narodowego zasobu archiwalnego? [w:] Pamiętnik VI Powszechnego Zjazdu Archiwistów Polskich, s. 20.

19 T. Czarnota, Oddziaływanie państwa na niepaństwowy zasób archiwalny w Polsce - od teorii do praktyki, „Wschodni Rocznik Humanistyczny”, t. 13, 2017, s. 304. 
archiwalnej dobrowolnie przekazywanej przez podmioty niezdolne do jej długotrwałego przechowywania we własnym zakresie lub tym niezainteresowane; d) udzielanie różnych form instruktażu, konsultacji, ekspertyz itp. o charakterze doraźnym, zorientowanych na usunięcie usterek lub wyjaśnienie konkretnych problemów i wątpliwości (zwłaszcza dotyczących sposobu oceny, opracowania i przechowywania dokumentów); e) cykliczne organizowanie kursów, konferencji metodycznych, warsztatów itp.; f) przekazywanie do użytku posiadanych narzędzi informacji archiwalnej (baz danych) bądź udzielanie dostępu do administrowanych przez siebie systemów; g) nieodpłatne świadczenie ad hoc nieskomplikowanych usług digitalizacyjnych lub konserwatorskich; h) przeprowadzanie przewidzianych w nowej wersji ustawy archiwalnej konkursów dotacyjnych, wspierających realizację zadań publicznych w zakresie ewidencjonowania, przechowywania, opracowywania, udostępniania lub zabezpieczenia materiałów archiwalnych; i) realizacja wspólnych przedsięwzięć o charakterze edukacyjnym, popularyzatorskim i naukowym, których „efektem ubocznym” byłoby budowanie trwałych relacji pomiędzy państwową służbą archiwalną i jej naturalnymi partnerami $z$ otoczenia ${ }^{20}$.

Z kolei w ramach pośredniego oddziaływania państwa, a szczególnie państwowej służby archiwalnej T. Czarnota wyróżnia kilka obszarów, a mianowicie: a) uczestniczenie $\mathrm{w}$ tworzeniu prawa powszechnie obowiązującego $\mathrm{z}$ uwzględnieniem interesów i potrzeb podmiotów z ewidencjonowanego niepaństwowego zasobu archiwalnego dotyczących sfery archiwalnej; b) tworzenie wskazówek metodycznych uwzględniających problemy wynikające ze specyfiki zbiorów dokumentów formujących się u aktotwórców niepaństwowego zasobu; c) opracowywanie własnych i/lub upowszechnianie cudzych archiwalnych i im pokrewnych standardów i norm, fachowej literatury i wszelkich „dobrych praktyk”; d) prowadzenie we własnym zakresie badań ukierunkowanych na uchwycenie szczególnego charakteru działalności archiwalnej i dokumentacyjnej w wydaniu niepaństwowych podmiotów; e) systematyczne monitorowanie sytuacji na dostępnym poszczególnym instytucjom państwowym wycinku zasobu i inicjowanie działań służących optymalizacji owego monitoringu; f) prowadzenie przemyślanej, długofalowej polityki informacyjnej dotyczącej prezentowania działań państwowej służby archiwalnej mogących zainteresować podmioty z ewidencjonowanego niepaństwowego zasobu archiwalnego; g) budowanie własnego prestiżu i autorytetu przez instytucje publiczne, przede wszystkim przez archiwa państwowe,

20 Ibidem, s. 294-295. 
z intencją jego wzmocnienia także w świadomości niepaństwowych podmiotów, czego dalszym skutkiem może być skłonienie ich do nawiązania, podtrzymania lub zintensyfikowania współpracy z państwem ${ }^{21}$.

Powyższa, obszerna lista obszarów oddziaływań archiwów państwowych wynika z zapisów prawa i powinna być, przynajmniej częściowo, odzwierciedlona w działaniach. Tymczasem, jak przyznają przedstawiciele państwowej służby archiwalnej, formalnie istniejący nadzór państwa nad niepaństwowym zasobem w praktyce objawia się jego ograniczonym wpływem na sposób przechowywania, zarządzania i udostępniania dokumentacji sektora prywatnego, gdyż o tym samodzielnie decydują podmioty $\mathrm{z}$ tego sektora ${ }^{22}$; „Kontrola archiwów państwowych nad postępowaniem z niepaństwowym zasobem archiwalnym jest bardzo ograniczona prawnie, a w praktyce po prostu nie funkcjonuje"23, mamy do czynienia z fikcją prawną ${ }^{24}$. Działania podejmowane w tym obszarze obarczone są zasadniczym mankamentem - wycinkowe, doraźne i w bardzo niewielkim stopniu skoordynowane. Znamionują brak całościowej wizji na oddziaływanie państwa na sektor niepaństwowego. Prawdopodobnie wynika to głównie z niedostrzegania na większą skalę przez państwową służbę archiwalną znaczenia czynników społecznych nadających coraz wyraźniej ton życiu publicznemu, co przyznają sami jej przedstawiciele ${ }^{25}$.

Przechodząc od zagadnień nowelizacji ustawy archiwalnej do analiz działalności archiwalnej, określić należy jej zakres. Działalność archiwalna to całokształt wykonywanych przez archiwa czynności, takich jak gromadzenie, przechowywanie, zabezpieczanie, opracowywanie i udostępnianie materiałów archiwalnych. Ich przedmiotem są archiwalia, czyli dokumentacja bez względu na jej postać fizyczną, mająca znaczenie jako źródło informacji o wartości historycznej i z tego powodu przechowywana wieczyście. Wartość informacyjna materiałów archiwalnych powodujepotrzebę , z jednej strony, otoczenia ich szczególną ochroną, z drugiej

${ }^{21}$ Ibidem.

${ }^{22}$ Pogląd byłego Naczelnego Dyrektora Archiwów Państwowych, prof. Władysława Stępniaka z 2013 r. [w:] Archiwiści chcq zabezpieczyć dokumentację sektora prywatnego, <http://www. dzieje.pl/aktualności/ archiwisci-chca-zabezpieczyc-dokumentacje-sektora-prywatnego $>$, [dostęp 16.09.2020].

${ }^{23}$ E. Łaborewicz, Zespoły aktowe partii politycznych, organizacji podległych i ruchów społecznych oraz związków i stowarzyszeń w zasobie Archiwum Państwowego we Wrocławiu Oddziat w Legnicy, s. 3, <https://www.archiwalna. archiwa.gov.pl/images /stories/file/pdf/zespoły_aktowe. $\mathrm{pdf} />$, [dostęp 16.09.2020].

${ }^{24}$ T. Czarnota., Oddziaływanie państwa, s. 304.

${ }^{25}$ W. Stępniak, op. cit., s. 11. 
zaś, umożliwienia wykorzystywania ich zarówno do naukowego poznawania przeszłości, jak i do zaspokajania innych potrzeb - administracyjnych, edukacyjnych, kulturalnych ${ }^{26}$.

Działalność archiwalną realizuje Państwowa Służba Archiwalna, działająca w oparciu o ustawę archiwalną. Nadzór nad zasobami archiwalnymi sprawuje Minister Kultury i Dziedzictwa Narodowego przez Naczelnego Dyrektora Archiwów Państwowych, który jest centralnym organem administracji państwowej w sprawach państwowego zasobu archiwalnego.

Obowiązek współdziałania $\mathrm{z}$ organizacjami pozarządowymi spada również na organy administracji archiwalnej, w szczególności na Naczelnego Dyrektora Archiwów Państwowych, poprzez art. 5 ust. 1 ustawy o działalności pożytku publicznego i o wolontariacie ${ }^{27}$. Ogólny obowiązek współdziałania wynika także z tzw. zasady pomocniczości, wyrażonej w Preambule Konstytucji RP ${ }^{28}$, która polega na przekazywaniu części obowiązków państwa ze szczebli centralnych na szczeble lokalne, bliższe obywatelowi, jak również działalności państwa wynikającej z obowiązku współpracy administracji publicznej z organizacjami pozarządowymi.

Współpraca ta odbywać się winna na zasadach pomocniczości, suwerenności stron, partnerstwa, efektywności, uczciwej konkurencji i jawności, zgodnie z zapisem art. 5 ust. 3. Może ona przybierać także postać wzajemnego informowania się, konsultowania projektów aktów normatywnych, tworzenia wspólnych zespołów o charakterze doradczym i inicjatywnym czy najbardziej zaawansowaną - zlecania realizacji zadań publicznych na zasadach określonych w tej ustawie ${ }^{29}$. Natomiast art. 45 ust. 4 ustawy archiwalnej przewiduje ustanawianie formalnych podstaw współpracy niepaństwowych jednostek organizacyjnych z państwową siecią archiwalną, w postaci porozumień zawieranych przez nie.

Uczestnictwo w kształtowaniu procesu legislacyjnego archiwa państwowe wpisały do swojej strategii na lata $2010-2020^{30}$. Strategia jest przejawem długofalowego

${ }^{26}$ M. Konstankiewicz, Ksztaltowanie podstaw prawnych, s. 339.

${ }^{27}$ Ustawa z dnia 24 kwietnia 2003 r. o działalności pożytku publicznego i o wolontariacie (Dz.U. 2020 poz. 1057).

${ }^{28}$ Konstytucja Rzeczypospolitej Polskiej z dnia 2 kwietnia 1997 r. (Dz.U. 1997 nr 78 poz. 483) (Dz.U. $2009 \mathrm{nr} 114$ poz. 946).

29 M. Konstankiewicz, Polityka państwa wobec archiwów społecznych w latach 2005-16, [w:] Archiwistyka społeczna. Diagnoza i wyzwania, red. E. Kołodziejska, Warszawa 2017, s. 49.

${ }^{30}$ Strategia Archiwów Państwowych na lata 2010-2020, <https://www.archiwa.gov.pl/images/ docs/Strategia_Archiwow_panstwowych_na_lata_2010_2020.pdf/>, [dostęp 16.09.2020]. 
planu działania, określającym główne cele i kierunki rozwoju polskich archiwów państwowych. W planowanej strategii Naczelna Dyrekcja Archiwów Państwowych, mając świadomość silnych i słabych stron, pragnie lepiej wykonywać ustawowe zadania archiwów państwowych, zwiększyć sprawność i dążyć do poprawy zarządzania posiadanymi zasobami. Udział w procesie legislacyjnym, w tym wprowadzenie do ustawy archiwalnej zapisów o możliwości ogłaszania przez NDAP konkursów na realizację zadań publicznych w odniesieniu do ewidencjonowania, opracowywania itd. archiwaliów jest odbiciem realizacji postulatów strony społecznej i uznać go należy za duży wkład na drodze poprawy wizerunku archiwów.

Ustawa archiwalna w szerokim zakresie przyznaje swobodę ustalania zasad ochrony i kształtowania ewidencjonowanego niepaństwowego zasobu archiwalnego oraz trybu jego udostępniania ${ }^{31}$, a podział zasobu niepaństwowego na ewidencjonowany i nieewidencjonowany ${ }^{32}$ uzależniony jest od statusu i rangi właścicieli. Sposób ewidencjonowania także jest pozostawiony uznaniu właścicieli materiałów archiwalnych, a wobec braku przepisów ustanawiających jakiekolwiek zasady $\mathrm{w}$ tej mierze lub przyznających zwierzchnie kompetencje administracji archiwalnej jest właściwie przepisem martwym.

Warto zauważyć, że z podziałem zasobu niepaństwowego na ewidencjonowany i nieewidencjonowany wiążą się także różnice w zakresie ograniczeń w korzystaniu z prawa własności. Na materiały należące do zasobu ewidencjonowanego nałożony jest zakaz zbywania, natomiast materiały wchodzące do zasobu nieewidencjonowanego nie mogą być jedynie wywożone za granicę bez zezwolenia, a obrót nimi jest ograniczony prawem pierwokupu przysługującym archiwom państwowym i wyodrębnionym ${ }^{33}$.

Z zapisów ustawy archiwalnej z 1983 r. wynika, że selekcji twórców materiałów archiwalnych dokonuje się a priori. Jak zaznacza Ewa Perłakowska:
(...) działanie to (...) rzutuje na określenie statusu niewybranych jednostek organizacyjnych i ich dokumentacji. Wywołuje też błędy w interpretacji zapisów ustawy archiwalnej poprzez przenoszenie zasad i regulacji prze- widzianych dla państwowych i samorządowych jednostek organizacyjnych na podmioty niepaństwowe ${ }^{34}$.

\footnotetext{
${ }^{31}$ Rozdział 4 Ustawy archiwalnej, art. 45 ust. 2 (Dz.U. 2020 poz. 164).

32 Ibidem, art. 41 ust 1 (Dz.U. 2020 poz. 164).

${ }^{33}$ M. Konstankiewicz, Prawne regulacje, s. 147.

${ }^{34}$ E. Perłakowska, Dotychczasowe kryteria wyłaniania twórców materiałów archiwalnych a wyzwania współczesności, [w:] Problemy wartościowania dokumentacji współczesnej, s. 7.
} 
Tymczasem we współczesnej administracji, w imię decentralizacji zarządzania państwem, organy administracji chętnie korzystają z możliwości przekazywania zadań innym podmiotom, w tym prywatnym. Oznacza to, że „kryterium znaczenia aktotwórcy ma coraz mniejsze znaczenie, a często wręcz mylące" i skutkuje wyciąganiem błędnych wniosków, że jeżeli jakiś podmiot (prywatny lub państwowy czy samorządowy) nie znajduje się na bieżąco w sferze zainteresowania archiwów, to nie wytwarza materiałów archiwalnych ${ }^{35}$.

Warto też zaznaczyć, że ustawowa regulacja podziału państwowych i samorządowych jednostek organizacyjnych na wytwarzające materiały archiwalne i te, które nie wytwarzają materiałów archiwalnych, wpłynęła na ugruntowanie stanowiska, że wszystkie jednostki, które nie zostały ustalone przez archiwa państwowe jako wytwarzające materiały archiwalne, nie mają cennej dokumentacji. A w dodatku pozbawiła dokumentację niearchiwalną ochrony prawnej przed nieuprawnionym zniszczeniem ${ }^{36}$. Przykładem są materiały archiwalne organów samorządu zawodowego adwokatów, które weszły w skład niepaństwowego zasobu archiwalnego, w związku z tym zostały wyłączone ze sfery oddziaływania archiwów państwowych. Także materiały archiwalne instytucji spółdzielczych, organizacji społecznych i zrzeszeń prywatnych weszły w skład niepaństwowego zasobu archiwalnego, jak również materiały archiwalne organizacji społecznych, stowarzyszeń, związków i innych instytucji społecznych, które włączono do niepaństwowego zasobu archiwalnego, a w związku z tym wyłączono ze sfery oddziaływania archiwów państwowych ${ }^{37}$.

We wspomnianej nowelizacji ustawy z $2007 \mathrm{r}$. zostały uchylone przepisy ustawy dotyczące prowadzenia rejestru niepaństwowego zasobu archiwalnego i od tego momentu brakuje mechanizmów służących kompleksowemu gromadzeniu informacji o niepaństwowych zbiorach archiwalnych. Wskazany rejestr był narzędziem, mającym ujmować jedynie te podmioty, które dobrowolnie wnioskowały o wpisanie do niego - co zapewne miało wpływ na jego faktyczne prowadzenie.

Jedynym narzędziem oddziaływania na tę sferę pozostaje możliwość zawierania przez ministra właściwego do spraw kultury porozumień z odpowiednimi

\footnotetext{
Zob. <https://www.archiwa.gov.pl//pl/dla-uzytkownikow/wydawnictwa/e-publikacje/problemywarto $\% \mathrm{C}_{5} \% 9$ Bciowania-dokumentacji-wsp\% $\mathrm{C}_{3} \% \mathrm{~B}_{3} \% \mathrm{C}_{5} \% 82$ czesnej.pdf/>, [dostęp 16.09.2020].

${ }^{35}$ Ibidem, s. 8.

36 Ibidem.

37 Ibidem, s. 13-16.
} 
podmiotami w sprawie współpracy archiwów niepaństwowych z państwową siecią archiwalną ${ }^{38}$.

W ramach zakresu działalności archiwalnej mieści się również przejmowanie archiwaliów z zasobu niepaństwowego na własność państwa, czyli włączanie ich do państwowego zasobu archiwalnego. Dla ewidencjonowanego zasobu może to nastąpić na mocy decyzji jej dotychczasowego właściciela lub w razie likwidacji niepaństwowej jednostki organizacyjnej ${ }^{39}$. Warto dodać, że w przypadku bibliotek i muzeów przejmowanie przez nie nowych archiwaliów jest ograniczone z zasady właśnie do materiałów proweniencji prywatnej ${ }^{40}$.

Prywatni właściciele materiałów archiwalnych od samego początku mieli ustawowo zagwarantowaną swobodę w sprawach kwalifikowania swej dokumentacji do materiałów archiwalnych i ich udostępniania. Obejmują ich jedynie ogólny obowiązek ochrony i ewidencjonowania archiwaliów, a także ograniczenia w obrocie nimi oraz w przekazywaniu i wywozie archiwaliów za granicę. Wspomnieć należy, że nie posiadają wymogu uzgadniania normatywów i dobrowolnie wdrażają instrukcję kancelaryjną, co jest następstwem nieobjęcia ich nadzorem państwowej służby archiwalnej. Ustawa obliguje również władze publiczne do sprawowania pieczy nad prywatnymi archiwaliami w celu zapewnienia ich ochrony jako świadectw przeszłości, ale zakres tych ingerencji i sposób ich dokonywania nie powinien naruszać istoty chronionego konstytucyjnie prawa własności ${ }^{41}$.

Istotnymi podmiotami tworzącymi ewidencjonowany niepaństwowy zasób archiwalny są organizacje pozarządowe (fundacje, stowarzyszenia, czy instytucje samorządowe (biblioteki itd.), które prowadzą archiwa społeczne. Mają na celu gromadzenie, przechowywanie, zabezpieczanie, opracowywanie, digitalizację i udostępnianie materiałów archiwalnych, tj. dokumenty, fotografie, nagrania audio i wideo.

Ostatnimi czasy zauważalnie wzrosło znaczenie archiwów społecznych związanych z działalnością organizacji pozarządowych. Wprawdzie przepisy ustawy archiwalnej ograniczają możliwość przenoszenia własności materiałów archiwalnych wytworzonych przez instytucje i stanowią tym samym pewną barierę formalną dla działalności archiwów społecznych, lecz nie uwzględniają w pełni ich potencjału w ogólnym modelu zabezpieczania archiwaliów podmiotów ${ }^{42}$.

\footnotetext{
${ }^{38}$ Rozdział 4 Ustawy archiwalnej, art. 45 ust 4 (Dz.U. 2020, poz. 164).

39 Art. 44 ustawy archiwalnej (Dz.U. 2020, poz. 164).

40 M. Konstankiewicz, Prawne regulacje, s. 147.

41 Idem, Kształtowanie podstaw prawnych, s. 353-354.

42 Ibidem, s. 346.
} 
Archiwa społeczne są to najczęściej instytucje pamięci gromadzące materiały niebędące wyłącznie wytworem jego dysponenta. Właściciel materiałów jednocześnie nie jest jednostką o charakterze państwowym lub samorządowym - nie jest nadzorowany przez struktury państwowe lub samorządowe. Nie jest również podmiotem kościelnym bądź komercyjnym, którego celem istnienia jest czerpanie zysków z gromadzenia dokumentacji, jak to jest w przypadku firm przechowalniczych. Archiwum społeczne może być zatem prowadzone przez jednostki trzeciego sektora, tj. fundacje i stowarzyszenia, organizacje pozarządowe, jak również osoby fizyczne czy partie polityczne, a w teorii również przedsiębiorstwa prywatne.

Archiwa społeczne to inicjatywy, które można sytuować częściowo w obrębie ewidencjonowanego, a częściowo w nieewidencjonowanym zasobie archiwalnym. Ich egzystowanie nie wpisuje się ściśle w podział oparty na zastosowaniu kryterium podmiotowego, zwłaszcza na odmiennościach statusu prawnego poszczególnych podmiotów. Kwestia dysponowania nimi przez podmioty o tym lub innym statusie jest $\mathrm{z}$ punktu widzenia istoty problemu i cech konstytutywnych ww. archiwów (np. oddolności podejmowanych działań) drugorzędna.

Istotą archiwów społecznych są więc dwie cechy: niepaństwowość, ich społeczna inicjatywa, jak również gromadzenie dokumentacji własnej i „obcej” niebędącej wytworem danej instytucji czy osoby, a jedynie przez nią zebranej lub nabytej od osób fizycznych - co odróżnia archiwa społeczne od archiwów bieżących, np. stowarzyszeń i fundacji czy archiwów prywatnych i rodzinnych ${ }^{43}$.

Pojęcie „archiwistyka społeczna” w zasadzie nie pojawiało się w przestrzeni publicznej do momentu, kiedy terminu szerzej używać zaczęła Fundacja Ośrodek KARTA na początku lat 9o. XX wieku. Wraz z wprowadzeniem go do powszechnej świadomości okazało się, że wiąże się z nim niebagatelny problem braku regulacji prawnych, co sugestywnie opisuje Zbigniew Gluza na przykładzie ratowania archiwum Towarzystwa Przyjaciół Pamiętnikarstwa ${ }^{44}$. Wydarzenie to miało przypuszczalnie duży wpływ na powstanie regulacji prawnych obowiązujących obecnie.

W warunkach społeczeństwa demokratycznego organizacje pozarządowe, partie polityczne i związki zawodowe, czyli najważniejsi spośród wytwórców ewidencjonowanego niepaństwowego zasobu archiwalnego obok największych jednostek życia gospodarczego, mają duży wpływ na bieg spraw państwowych

${ }^{43}$ M. Wiśniewska, Funkcje archiwów społecznych, [w:] Archiwa organizacji pozarządowych $w$ Polsce, red. T. Czarnota, M. Konstankiewicz, Warszawa-Lublin 2015, s. 63-70.

${ }^{44}$ Gluza Z., Dekada przed archiwistyka społeczną, [w:] Archiwistyka społeczna, red. K. Ziętal, Warszawa 2012, s. 18-22. 
i życie społeczeństwa. Pełniąc ważną rolę w społeczeństwie obywatelskim, zobowiązują się także do zgodnego $\mathrm{z}$ wymogami prawa postępowania $\mathrm{z}$ wytwarzaną przez siebie dokumentacją i powstającymi w jej ramach materiałami archiwalnymi ${ }^{45}$. Idąc dalej za tokiem rozumowania Władysława Stępniaka, „uświadomić powinniśmy sobie fakt istnienia potrzeby prowadzenia aktywnej i świadomej polityki w tym zakresie" ${ }^{46}$.

W ustawie archiwalnej przewidziano funkcjonowanie archiwów organizacji pozarządowych generalnie jako archiwów przechowujących dokumentację własną, czyli wytworzoną w tej organizacji. Po części wynika to z zakazu zbywania materiałów archiwalnych wchodzących do państwowego zasobu archiwalnego, co powoduje, że interesujące nas podmioty nie mogą stać się właścicielami takich archiwaliów. Ponadto własność materiałów archiwalnych nie może być przedmiotem obrotu, co oznacza, że organizacja pozarządowa nie może przejąć archiwaliów wytworzonych przez inną niepaństwową jednostkę organizacyjną. Niedopuszczalne jest również przejęcie na własność materiałów archiwalnych należących do państwowego zasobu archiwalnego ${ }^{47}$.

Jedyny wyjątek od powyższej zasady przewiduje art. 45 ust. 3 ustawy archiwalnej, w myśl którego archiwa niepaństwowych jednostek organizacyjnych mogą obejmować również zasób historyczny w rozumieniu art. 25 ust. 2 tej ustawy ${ }^{48}$.

Powyższe ograniczenie, jako zabieg prawny ustawodawcy, obliczone jest zapewne na utrzymanie dominującej pozycji archiwów państwowych w strukturze archiwalnej w Polsce. W świetle przedstawionych powyżej supozycji nie od rzeczy byłoby wskazanie na potrzebę dyskusji nad celowością dalszego utrzymania tego zapisu w obecnym kształcie, ustanowionego w jakże odmiennych i ogólnie krytykowanych warunkach ustrojowych zapisu ustawowego.

Pod wpływem narastającego zainteresowania działaniami archiwów społecznych, dzięki wspomnianej wyżej nowelizacji ustawy z 2015 r., pojawił się prawny mechanizm służący wspieraniu przez państwo działalności archiwalnej podmiotów prywatnych. W świetle art. 43 Naczelny Dyrektor Archiwów Państwowych posiada uprawnienia do zlecania organizacjom pozarządowym realizacji zadań publicznych w zakresie ewidencjonowania, przechowywania, opracowania, udostępniania lub zabezpieczenia materiałów archiwalnych stanowiących

\footnotetext{
${ }^{45}$ W. Stępniak, op. cit., s. 11-13.

${ }^{46}$ Ibidem, s. 14-15.

${ }^{47}$ M. Konstankiewicz, Aspekty teoretyczne i prawne działalności archiwalnej organizacji pozarządowych, [w:] Archiwa organizacji pozarzadowych w Polsce, s. 54.

${ }^{48}$ Ibidem.
} 
ewidencjonowany niepaństwowy zasób archiwalny ${ }^{49}$. Nowelizacja otwiera możliwość organizowania konkursów dotacyjnych dla organizacji pozarządowych posiadających materiały archiwalne. Na nowo układa relacje państwo-archiwa społeczne, dając naczelnej dyrekcji narzędzie do współpracy i do pomocy w trwałym zabezpieczeniu społecznych zbiorów. ${ }^{50}$

Jak zauważa Marek Konstankiewicz, „przepisy ustawy archiwalnej dotyczące dostępu do niepaństwowego zasobu archiwalnego mają niezmieniony od początku kształt i charakter w gruncie rzeczy szczątkowy" ${ }^{\prime 2}$.

W konkluzji podsumujmy zatem najważniejsze: właścicielom archiwaliów omawianego zasobu zagwarantowano autonomię w zakresie ustalania zasad ich udostępniania. Istotne $\mathrm{w}$ tej sytuacji są inne regulacje, np. przepisy o ochronie danych osobowych lub w pewnych sytuacjach o dostępie do informacji publicznej ${ }^{52}$. Wspomnieć należy, że właściciele archiwaliów nie posiadają także wymogu uzgadniania normatywów i dobrowolnie wdrażają instrukcję kancelaryjną. Jednak należy pamiętać, że na materiały należące do zasobu ewidencjonowanego nałożony jest zakaz zbywania. Ponadto, sektor prywatny posiada ustawowo nałożony obowiązek sprawowania pieczy nad materiałami archiwalnymi i zapewnienia im odpowiedniej ochrony, wynikający głównie z art. 12 ustawy archiwalnej, choć praktycznie wiodące znaczenie dla tej grupy aktotwórców ma prawo autorskie, przepisy o ochronie danych osobowych, niekiedy też o dostępie do informacji publicznej oraz szereg regulacji szczególnych ${ }^{53}$. Do tego dochodzi prawo współpracy archiwów państwowych z podmiotami prywatnymi, a dyrektorzy archiwów państwowych, kierując się wytycznymi NDAP ${ }^{54}$, przeprowadzają rozpoznanie liczby i rodzajów podmiotów, z którymi wskazane jest kontynuowanie lub nawiązanie współpracy. Po zaniechaniu w 2007 r. prowadzenia rejestru niepaństwowego zasobu archiwalnego i przymusie przejęcia na przechowanie w archiwum państwowym materiałów archiwalnych w razie ich zagrożenia, a także zlikwidowaniu

${ }^{49}$ M. Konstankiewicz, Kształtowanie podstaw prawnych, s. 354.

50 A. Jóźwik, Wstęp, [w:] Archiwistyka społeczna. Diagnoza i wyzwania, red. E. Kołodziejska, Warszawa 2017, s. 8-9.

${ }^{51}$ M. Konstankiewicz, Autoreferat pracy doktorskiej, s. 15.

${ }^{52}$ Idem, Prawne regulacje, s. 147.

${ }_{53}$ M. Konstankiewicz, Status archiwum bieżącego we współczesnym polskim prawie archiwalnym, [w:] Zarządzanie dokumentacją, archiwistyka i... koty. Księga jubileuszowa Profesor Haliny Robótki, red. R. Degen, M. Jabłońska, W. K. Roman, Warszawa 2016, s. 94.

${ }^{54}$ Zarządzenie $\mathrm{Nr} 39$ z 26 kwietnia 2018 r. w sprawie współpracy archiwów państwowych z podmiotami, których materiały archiwalne wchodzą w skład ewidencjonowanego niepaństwowego zasobu archiwalnego. 
możliwości wypłacania ekwiwalentu za nakłady związane z przechowywaniem, zabezpieczeniem i konserwacją materiałów archiwalnych wchodzących do niepaństwowego zasobu archiwalnego, przyszła spóźniona refleksja.

W roku 2015 wprowadzono mechanizm wspierania działalności archiwalnej organizacji pozarządowych oraz zmodyfikowano zasady przejmowania archiwaliów z niepaństwowych jednostek organizacyjnych do archiwów państwowych. Jednak samo słowo „przejmowanie” używane w kontekście odbierania przez jeden podmiot drugiemu jego własności, nawet jeśli działoby się to za jego zgodą, nie wywołuje pozytywnych konotacji i wydaje się ono nader nieodpowiednie w stosunku do podmiotów niepaństwowych, które nie mają takiego obowiązku ${ }^{55}$.

Nowelizacja otwiera możliwość organizowania konkursów dotacyjnych dla organizacji pozarządowych posiadających materiały archiwalne. Dotyczy to jedynie podmiotów prawnych (Ustawa o organizacjach pożytku publicznego), co eliminuje z kręgu potencjalnych beneficjentów konkursów archiwa społeczne bez podmiotowości prawnej (jak i inne, np. będące „składową” podmiotu gospodarczego).

Dodany do ustawy archiwalnej w 2015 r. art. 43a daje podstawę prawną pierwszemu i jak dotąd jedynemu finansowemu mechanizmowi wspierania przez Państwo działalności archiwalnej instytucji prywatnych i zlecania realizacji zadań publicznych w zakresie ewidencjonowania, przechowywania, opracowania, udostępniania lub zabezpieczenia materiałów archiwalnych stanowiących ewidencjonowany niepaństwowy zasób archiwalny ${ }^{56}$.

Niepaństwowa jednostka organizacyjna może zawrzeć porozumienie z ministrem nadzorującym narodowy zasób archiwalny, które określałoby zasady współpracy $\mathrm{z}$ archiwami państwowymi podległymi naczelnemu dyrektorowi archiwów państwowych. Ustawodawca nie zobowiązał jednak twórców ewidencjonowanego niepaństwowego zasobu archiwalnego do zawierania obligatoryjnych porozumień z naczelnym dyrektorem archiwów państwowych w zakresie postępowania z materiałami archiwalnymi należącymi do narodowego zasobu archiwalnego. Nie narzucał także ramowych warunków takiego porozumienia, np. dotyczących prawa nadzoru archiwów państwowym nad kształtowaniem dokumentacji, jej wartościowania i brakowania oraz przechowywania materiałów archiwalnych, zwłaszcza stanowiących zasób historyczny ${ }^{57}$.

\footnotetext{
55 T. Czarnota, Oddziaływanie państwa, s. 302.

56 Ibidem, s. 52.

57 R. Galuba, op. cit., s. 48.
} 
Dostęp do materiałów archiwalnych może zostać również ograniczony ze względu na zły stan fizyczny tych materiałów, ochronę dóbr osobistych i danych osobowych, a także w zakresie i na zasadach określonych w przepisach o ochronie informacji niejawnych oraz o ochronie innych tajemnic ustawowo chronionych ${ }^{58}$. Prawo do informacji publicznej podlega ograniczeniu w zakresie i na zasadach określonych $\mathrm{w}$ przepisach o ochronie informacji niejawnych oraz o ochronie innych tajemnic ustawowo chronionych, ze względu na prywatność osoby fizycznej lub tajemnicę przedsiębiorcy ${ }^{59}$. W pewnych aspektach ujemnie wpływa na proces udostępniania materiałów archiwalnych. Zgodnie z orzeczeniem Naczelnego Sądu Administracyjnego (sygn. akt I OSK 1258/16), dokumenty znajdujące się $\mathrm{w}$ archiwach zakładowych stanowią informację publiczną i nie można odmówić ich udostępnienia na podstawie przepisów o narodowym zasobie archiwalnym $\mathrm{i}$ archiwach. Jak wynika $\mathrm{z}$ art. 35 ust. 2 ustawy o narodowym zasobie archiwalnym i o archiwach, zasób archiwalny archiwów zakładowych stanowią materiały archiwalne powstałe i powstające $\mathrm{w}$ związku $\mathrm{z}$ działalnością jednostek organizacyjnych, w których zostały utworzone. Oznacza to, że w istocie nie tylko wszystko to, co już powstało $\mathrm{w}$ związku z działalnością danego podmiotu wykonującego zadania publiczne i co stanowi archiwum zakładowe, ale także i to, co powstaje w związku z taką działalnością, jest objęte pojęciem zasobu archiwalnego archiwów zakładowych. Stanowiłoby to wystarczającą formę w istocie do całkowitego lub prawie całkowitego uniemożliwienia realizacji ustawy o dostępie do informacji publicznej i konstytucyjnej zasady gwarantującej taki dostęp ${ }^{60}$.

Wspominano, że według obowiązujących przepisów, dyrektorzy archiwów państwowych powinni przeprowadzić rozpoznanie podmiotów, które tworzą lub przechowują materiały archiwalne wchodzące w skład ewidencjonowanego niepaństwowego zasobu archiwalnego, w celu sporządzenia i aktualizacji ich wykazu. Zgodnie z art. 45 ust. 4 ustawy archiwalnej, są również zobowiązani do przesyłania do danego podmiotu oferty kontynuowania lub nawiązania współpracy, określając jej zakres, oraz informacji o możliwości zawarcia porozumienia. Natomiast pewne wątpliwości budzi treść art. 44 ust. 1 ustawy archiwalnej, który stanowi, że z chwilą ustania działalności jednostki organizacyjnej jej materiały archiwalne stają się własnością państwa i podlegają przekazaniu do właściwej

\footnotetext{
${ }^{58}<$ https://www.archiwa.gov.pl/pl/dla-uzytkownikow/warunki-udost\%C4\%99pniania-zasobu-archiwum>, [dostęp 16.12.2020].

${ }^{59}$ Ustawa z dnia 6 września 2001 r. o dostępie do informacji publicznej (Dz. U. z 2018 r., poz. $1330 \mathrm{z}$ późn. zm.).

${ }^{60}<$ http://www.orzeczenia.nsa.gov.pl/doc/122F2004E3>, [dostęp: 16.12.2020].
} 
jednostki państwowej sieci archiwalnej. Wydaje się, że jest to dość poważne ograniczenie samodzielności między innymi organizacji pozarządowych w dysponowaniu własnym majątkiem, będące $w$ istocie wywłaszczeniem dokonywanym wobec milczenia przepisu bez odszkodowania. Takie rozwiązanie jest sprzeczne z przynajmniej jedną przesłanką dopuszczającą tego rodzaju regulacje, które wskazano w art. 21 ust. 2 Konstytucji RP ${ }^{61}$.

Wątpliwości jest więcej: czy ustanowienie monopolu archiwów państwowych na gromadzenie archiwaliów wytworzonych przez instytucje prywatne rzeczywiście jest najlepszym sposobem zabezpieczenia ich spuścizny dokumentacyjnej wobec potencjału bibliotek lub archiwów społecznych? ${ }^{62}$.

Rola państwa i jego instytucji zmienia się, a państwo „kurczy się”, coraz więcej zadań powierzając instytucjom, firmom prywatnym lub społecznym. W nowej rzeczywistości należałoby rozszerzyć $i$ jeszcze raz ustanowić obowiązki archiwizowania dokumentów także przez inne niż państwowe podmioty i jednostki organizacyjne. W tym modelu archiwa wyznaczałyby nie tylko jednostki państwowe jako wytwarzające materiały archiwalne, ale również jednostki niepaństwowe. Kryterium doboru stanowiłaby społeczna, wieczysta użyteczność tworzonej dokumentacji ${ }^{63}$. Nie mogą w tych warunkach dziwić oddolne inicjatywy społeczne, mające na celu ratowanie narodowego dziedzictwa archiwalnego. Za przykład należy podać działalność Fundacji Ośrodka KARTA, propagującego idee archiwistyki społecznej oraz potrzebę koordynacji działań instytucji i organizacji pozarządowych, przy równoczesnym finansowaniu ich działalności ze strony państwa ${ }^{64}$. Twórcy ewidencjonowanego niepaństwowego zasobu archiwalnego, uczestnicząc w życiu publicznym, wpływają na zachodzące procesy społeczne, polityczne, kulturalne czy gospodarcze, a biorąc udział - jak w przypadku partii politycznych - w rządzeniu krajem, powinni trwale przechowywać swoją dokumentację i zapewniać dostęp do niej zainteresowanym obywatelom, zaś „współpraca z władzami państwowymi, w tym z archiwami państwowymi, jest oczywiście bardzo ważna dla obu stron. Nie powinna ona jednak podważać niezależnej od czynników państwowych pozycji tych instytucji”65.

Z racji dynamicznego rozwoju archiwistyki społecznej konieczne jest zbudowanie modelu, który zarówno stworzy centralną ewidencję informacji o posiadanych

\footnotetext{
${ }^{61}$ R. Galuba, op. cit., s. 55.

${ }^{62}$ M. Konstankiewicz, Kształtowanie podstaw prawnych, s. 354.

${ }^{63}$ E. Borodij, op. cit., s. 174.

64 W. Stępniak, op. cit., s. 12-13.

65 Ibidem, s. 13.
} 
przez archiwa społeczne zbiorach archiwalnych, jak i przeciwdziałać będzie powstawaniu zagrożeń dla cennych materiałów historycznych. Według opinii Fundacji Ośrodka KARTA przywrócenie rejestru gwarantowałoby powszechny dostęp do informacji o gromadzonych przez archiwa społeczne zbiorach. W przypadku likwidacji archiwum społecznego przedstawiciele archiwów państwowych mieliby wiedzę, jak mogą uratować od zniszczenia zgromadzony zasób archiwalny. Do tego archiwa społeczne mogłyby liczyć także na pozafinansowe wsparcie ze strony Naczelnej Dyrekcji Archiwów Państwowych ${ }^{66}$.

Fundacja Ośrodka KARTA od 2012 r. ewidencjonuje polskie archiwa społeczne w ogólnodostępnej bazie, opublikowanej na stronie www.archiwa.org. Według definicji przyjętej przez Fundację Ośrodek KARTA Archiwum społeczne powstaje w efekcie celowej oddolnej działalności obywatelskiej. Jego główną misją jest aktywne działanie na rzecz ratowania i ochrony dziedzictwa kulturowego, a celem - pozyskiwanie, zabezpieczanie, opracowanie i udostępnianie materiałów wchodzących w skład niepaństwowego zasobu archiwalnego. W definicji tej kładziony jest nacisk przede wszystkim na cele, misję i ideę archiwum społecznego, nie zaś na podmiot, który to archiwum prowadzi. Wynika z niej przede wszystkim, że archiwum takie powinno aktywnie działać na rzecz ochrony materiałów archiwalnych oraz realizować cele typowe dla archiwów (zabezpieczanie, opracowanie, udostępnianie materiałów archiwalnych). Materiały archiwalne, które archiwum zabezpiecza, należą do niepaństwowego zasobu archiwalnego ${ }^{67}$.

Podsumowując niniejsze rozważania, należy uznać, że sytuacja ewidencjonowanego niepaństwowego zasobu archiwalnego jest dość skomplikowana. Trudności w stworzeniu stabilnej regulacji i obecna dynamika zmian zachodzących w rzeczywistości, a także niedoskonałości legislacji wpływają na stan zasobu.

W konkluzji sięgnąć jeszcze należy po wypowiedzi na te tematy $\mathrm{z}$ ostatnich lat, pochodzące od przedstawicieli kierownictwa państwowej służby archiwalnej, warto zatem przytoczyć opinię Wojciecha Woźniaka - Naczelnego Dyrektora Archiwów Państwowych w latach 2016-2018:

Problemy systemu polskiej archiwistyki zorganizowanego wokół definicji państwowego i niepaństwowego zasobu archiwalnego ogniskują się właśnie w kwestii archiwów społecznych. Nie sposób nie dostrzec wagi

${ }^{66}$ A. Jóźwik, op. cit., s. 10.

${ }^{67}$ K. Ziętal, Archiwa społeczne w Polsce - prezentacja i analiza wyników badań, [w:] Archiwistyka społeczna., s. 14. 
i znaczenia materiałów archiwalnych zgromadzonych w tego rodzaju instytucjach, jak i nie sposób zignorować ich nierzadko niezwykle społecznie doniosłej działalności. Wydaje się, ze najważniejszym zadaniem w tym zakresie jest zadbanie o wspólny system informacji o zasobie archiwalnym tak, aby zasoby archiwów społecznych były dostępne równie łatwo jak zasoby archiwów państwowych. Archiwa państwowe mogą i powinny być dostarczycielem wzorców dla archiwów społecznych w zakresie zarówno metodyki, jak standardów przechowywania czy zabezpieczania zasobu. Niewątpliwie więc zadaniem archiwów państwowych jest dostrzeganie i wspieranie archiwów społecznych, zaś zadaniem archiwów społecznych kontynuowanie ich misji w ramach prawnych wyznaczonych przez obowiązujące obecnie prawo $^{68}$.

Na tle powyższych słów zauważalny jest trend w reorientowaniu zapatrywań archiwów państwowych w kontekście dostrzegania problemu współpracy z podmiotami niepaństwowego zasobu archiwalnego. Wydaje się oczywiste, że archiwiści państwowi powinni zmienić stosunek do ewidencjonowanego niepaństwowego zasobu archiwalnego i częściej spoglądać na niego, jak na materiały o znaczącej wartości historycznej, które stanowią cenne uzupełnienie zasobu państwowego. Wzbogacanie tego zasobu jest społecznie niezwykle istotne, a opracowywanie przez wykwalifikowaną kadrę jest wręcz konieczne, ponieważ tylko archiwa państwowe są w stanie zapewnić im kompleksową opiekę i nadzór. Tylko w ten sposób, wspólnymi siłami uda się prawidłowo zabezpieczać materiały proweniencji pozarządowej ${ }^{69}$.

Podział twórców materiałów archiwalnych według struktury własności był i nadal pozostaje w oderwaniu od najważniejszego czynnika decydującego o wartości historycznej materiałów archiwalnej - ich wartości informacyjnej, która jest często niezależna od struktury właścicielskiej jego twórcy. To utrwalony „relikt” czasów, w jakich uchwalono ustawę archiwalną, który należałoby poddać zmianie.

Pozostałe pytania: Czy powrócić do aktywnego prowadzenia rejestru podmiotów tworzących ewidencjonowany niepaństwowy zasób archiwalny? Czy zmienić

${ }^{68}$ W. Woźniak, Archiwistyka w Polsce - mapa współczesnych wyzwań, [w:] Pamiętnik VII Powszechnego Zjazdu Archiwistów Polskich. Kielce, 20-21 września 2017 r., red. W. Chorążyczewski, K. Stryjkowski, Warszawa 2013, s. 39.

${ }^{69}$ A. Kobylańskij, P. Opoka, Aktualne problemy archiwistyki i zarządzania dokumentami, I Międzynarodowe Seminarium Naukowo-Dydaktyczne, Lublin, 21 V 2016 r., „Archiwa - Kancelarie - Zbiory", nr 7, 2016, s. 187. 
termin „ewidencjonowany zasób archiwalny”, ponieważ w rzeczywistości nikt takowego rejestru nie prowadzi? - wymagają dalszej dyskusji. Tu trzeba zadać sobie pytanie: Czy przywracanie rejestru ma sens? Może wystarczyłoby sumienne $\mathrm{i}$ treściwe $\mathrm{w}$ formie publikowanie przez wszystkie archiwa państwowe corocznych zestawień z realizacji współpracy z podmiotami wytwarzającymi materiały archiwalne, które wchodzą w skład niepaństwowego zasobu archiwalnego, i sumaryczne publikowanie wyników przez NDAP?

Bardzo często informacje rozpowszechniane przez publicznych twórców materiałów archiwalnych wskutek kreatywnej polityki informacyjnej były i pozostają celowo niewiarygodne, aby ochronić określone interesy partykularne, lub wynikają z aktualnej sytuacji politycznej. Natomiast informacje tworzone przez niepublicznych twórców miały i mają bardzo często większą wartość historyczną lub stanowią cenne ich uzupełnienie ${ }^{70}$.

Państwo powinno rozszerzyć uprawnienia służby archiwalnej i w ramach kontynuacji strategii realizować cele wspierające nowe rozwiązania prawne w zakresie efektywnego zarządzania dokumentacją poprzez udział w procesie legislacyjnym, ustalanie przepisów metodycznych mających bezpośredni i zauważalny wpływ państwa na podmioty z niepaństwowego zasobu archiwalnego.

Państwo powinno również korzystać z istniejącej już i stale rosnącej sieci archiwów społecznych, dotować i wspierać oddolne inicjatywy, jak również czerpać korzyści z działalności instytucji niepaństwowych na polu archiwistyki społecznej.

Refleksją z powyższych rozważań jest wniosek, że wraz ze wzrostem znaczenia społeczeństwa obywatelskiego i przejścia w sferę prywatną działalności gospodarczej, wytwarzane i zgromadzone przez ten sektor materiały archiwalne stanowią ważne i trudne do zastąpienia źródło poznania przeszłości społeczeństwa i jego instytucji w różnych ich przejawach - dlatego należy o nie dbać i zabiegać.

\section{Summary}

\section{The Registered Non-State Archival Collection - Introduction to the Problem}

The registered non-state archival collection is one of the parts of the national archive collections. An important part of the national archival collection is the materials in possession of private entities that are not classified as part of the

\footnotetext{
${ }^{70}$ R. Galuba, op. cit., s. 35.
} 
public sector. The entities that are the owners of non-state archival collections are the addressees of few regulations that give them a large amount of autonomy in shaping the principles of the handling of the archival materials which are their property. With the growth of the importance of civil society and the transition into private economic activity, the archival materials produced and collected by this sector, constitute an important and difficult-to-replace source of knowing the past of society and its institutions. Grass-root social initiatives are aimed to save national archival heritage. The state should make use of the existing and still growing network of social archives, support and make use of non-state institutions in the field of social archives by propagating the ideas of social archive practices and the need to coordinate the actions of institutions and non-governmental organizations while at the same time financing their activity from state funds.

\section{Bibliografia}

\section{Źródła drukowane}

Dekret o organizacji archiwów państwowych i opiece nad archiwaliami z 7 lutego 1919 roku (Dz.Pr.P.P. $1919 \mathrm{nr} 14$ poz. 182).

Dekret z dnia 29 marca 1951 r. o archiwach państwowych (Dz.U. $1951 \mathrm{nr} 19$ poz. 149).

Ustawa z dnia 14 lipca 1983 r. o narodowym zasobie archiwalnym i archiwach, dalej określana jako ustawa archiwalna (Dz.U. 2020 poz. 164).

Konstytucja Rzeczypospolitej Polskiej z dnia 2 kwietnia 1997 r. (Dz.U. 1997 nr 78 poz. 483) (Dz.U. 2009 nr 114 poz. 946).

Ustawa z dnia 24 lipca 1998 r. o wprowadzeniu zasadniczego trójstopniowego podziału terytorialnego państwa (Dz.U. $1998 \mathrm{nr} 96$ poz. 603).

Ustawa z dnia 24 lipca 1998 r. o zmianie niektórych ustaw określających kompetencje organów administracji publicznej - w związku z reformą ustrojową państwa (Dz.U. 1998, nr 106, poz. 668).

Ustawa z dnia 18 grudnia 1998 r. o Instytucie Pamięci Narodowej - Komisji Ścigania Zbrodni przeciwko Narodowi Polskiemu (tekst jednolity Dz.U. 2018 poz. 2032, z późn. zm.).

Ustawa z dnia 24 kwietnia 2003 r. o działalności pożytku publicznego i o wolontariacie (Dz.U. 2020 poz. 1057).

Ustawa z dnia 17 lutego 2005 r. o informatyzacji działalności podmiotów realizujących zadania publiczne (Dz.U. z 2014 r. poz. 1114); 
Ustawa $\mathrm{z}$ dnia 2 marca 2007 r. o zmianie ustawy o narodowym zasobie archiwalnym i archiwach oraz ustawy - Kodeks pracy (Dz.U. 2007, nr 64, poz. 426).

Rozporządzenie Rady Ministrów z dnia 22 czerwca 2011 r. w sprawie sposobu i trybu udostępniania materiałów archiwalnych znajdujących się w archiwach wyodrębnionych (Dz.U. Nr 196, poz. 1161).

Ustawa z dnia 20 marca 2015 r. o zmianie ustawy o narodowym zasobie archiwalnym i archiwach (Dz.U. 2015, poz. 566).

Rozporządzenie Ministra Kultury i Dziedzictwa Narodowego z dnia 14 października 2015 r. w sprawie warunków i trybu przekazywania do archiwów państwowych materiałów archiwalnych tworzących ewidencjonowany niepaństwowy zasób archiwalny (Dz.U. 2015, poz. 1733).

Ustawa z dnia 25 lutego 2016 r. o ponownym wykorzystywaniu informacji sektora publicznego (Dz.U. 2016, poz. 352).

Rozporządzenie Parlamentu Europejskiego i Rady (UE) 2016/679 z dnia 27 kwietnia 2016 r. w sprawie ochrony osób fizycznych w związku z przetwarzaniem danych osobowych i w sprawie swobodnego przepływu takich danych oraz uchylenia dyrektywy 95/46/WE (ogólne rozporządzenie o ochronie danych).

Ustawa z dnia 10 maja 2018 r. o ochronie danych osobowych (Dz.U. z 2019 r. poz. 1781). Zarządzenie Nr 39 Naczelnego Dyrektora Archiwów Państwowych z dnia 26 kwietnia 2018 r. w sprawie współpracy archiwów państwowych z podmiotami, których materiały archiwalne wchodzą w skład ewidencjonowanego niepaństwowego zasobu archiwalnego (znoszące Zarządzenie Nr 16 z 10 grudnia 2012 r.).

Rozporządzenie Ministra Kultury i Dziedzictwa Narodowego z dnia 27 lipca 2018 r. w sprawie szczegółowego zakresu działania Naczelnego Dyrektora Archiwów Państwowych (Dz.U. poz. 1566).

\section{Literatura}

Borodij E., Potrzeby użytkowników a obecne kryteria wartościowania, [w:] Problemy wartościowania dokumentacji współczesnej - konferencja w Archiwum Głównym Akt Dawnych, 19-20 czerwca 2007 r., Warszawa 2007, s. 32-45.

Czarnota T., Problematyka działalności dokumentacyjnej współczesnych archiwów, [w:] Toruńskie konfrontacje archiwalne, t. 4, Nowa archiwistyka - archiwa i archiwistyka w ponowoczesnym kontekście kulturowym, red. W. Chorążyczewski, W. Piasek, A. Rosa, Toruń 2014, s. 53-70.

Czarnota T., Oddziaływanie państwa na niepaństwowy zasób archiwalny w Polsce - od teorii do praktyki, „Wschodni Rocznik Humanistyczny”, t. 13, 2017, s. 291-309. 
Galuba R., Archiwa organizacji pozarzadowych w polskim prawie archiwalnym 1918-2012, [w:] Archiwa organizacji pozarządowych w Polsce, red. T. Czarnota, M. Konstankiewicz, Warszawa-Lublin 2015, s. 29-50.

Gluza Z., Dekada przed archiwistyką społeczna, [w:] Archiwistyka społeczna, red. K. Ziętal, Warszawa 2012, s. 18-22.

Jóźwik A., Wstęp, [do:] Archiwistyka społeczna, [w:] Archiwistyka społeczna. Diagnoza i wyzwania, red. E. Kołodziejska, Warszawa 2017, s. 3-13.

Kobylańskij A., Opoka P., Aktualne problemy archiwistyki i zarzadzania dokumentami, I Międzynarodowe Seminarium Naukowo-Dydaktyczne, Lublin, 21 V 2016 r., „Archiwa - Kancelarie - Zbiory”, nr 7, 2016, s. 183-190.

Konstankiewicz M., Prawne regulacje działalności archiwalnej w Polsce (stan prawny $z$ dnia 1 stycznia 2010 roku), „Archiwa - Kancelarie - Zbiory”, nr 1, 2010, s. 131-151.

Konstankiewicz M., Autoreferat pracy doktorskiej <https://www.umcs.pl/szukaj-redirect,394018/>, [dostęp 16.09.2020].

Konstankiewicz M., Aspekty teoretyczne i prawne działalności archiwalnej organizacji pozarzadowych, [w:] Archiwa organizacji pozarzadowych w Polsce, red. T. Czarnota, M. Konstankiewicz, Warszawa-Lublin 2015, s. 51-62.

Konstankiewicz M., Status archiwum bieżącego we wspótczesnym polskim prawie archiwalnym, [w:] Zarządzanie dokumentacja, archiwistyka i... koty. Ksiega jubileuszowa Profesor Haliny Robótki, red. R. Degen, M. Jabłońska, W. K. Roman, Warszawa 2016, s. 93-104.

Konstankiewicz M., Polityka państwa wobec archiwów społecznych w latach 2005-16, [w:] Archiwistyka społeczna. Diagnoza i wyzwania, red. E. Kołodziejska, Warszawa 2017, s. 33-61.

Konstankiewicz M., Kształtowanie podstaw prawnych działalności archiwalnej w Polsce na przełomie XX i XXI w., „Archeion”, t. 120, 2019, s. 337-366.

Konstankiewicz M., Niewęgłowski A., Narodowy zasób archiwalny i archiwa. Komentarz, Warszawa 2016.

Łaborewicz E., Zespoły aktowe partii politycznych, organizacji podległych i ruchów społecznych oraz związków i stowarzyszeń w zasobie Archiwum Państwowego we Wrocławiu Oddział w Legnicy, s. 3 <https://archiwalna. archiwa.gov.pl/images / stories/file/pdf/zespoły_aktowe.pdf/>, [dostęp 16.09.2020].

Perłakowska E., Dotychczasowe kryteria wyłaniania twórców materiałów archiwalnych a wyzwania wspótczesności, [w:] Problemy wartościowania dokumentacji wspótczesnej-konferencja w Archiwum Głównym Akt Dawnych. 19-20 czerwca 2007 r., Warszawa 2007, s. 3-31. 
Stępniak W., Czy wiemy, czym jest instytucja narodowego zasobu archiwalnego? [w:] „Stowarzyszenie Archiwistów Polskich, Zatrzymać Przeszłość, Dogonić Przyszłość". Pamiętnik VI Powszechnego Zjazdu Archiwistów Polskich, Wrocław 5-7 września 2012 r., red. W. Chorążyczewski, K. Stryjkowski, Warszawa 2013, s. 11-22.

Wiśniewska M., Funkcje archiwów społecznych, [w:] Archiwa organizacji pozarządowych $w$ Polsce, red. T. Czarnota, M. Konstankiewicz, Warszawa-Lublin 2015, s. 63-70.

Wolnicki P., Podstawy współpracy państwowej służby archiwalnej w Polsce $z$ Kościołami i związkami wyznaniowymi,„Archeion”, t. 115, 2014, s. 153-166.

Woźniak W., Archiwistyka w Polsce - mapa współczesnych wyzwań, [w:] Pamiętnik VII Powszechnego Zjazdu Archiwistów Polskich. Kielce, 20-21 września 2017 r., red. W. Chorążyczewski, K. Stryjkowski, Warszawa 2013, s. 31-44.

Ziętal K., Archiwa społeczne. Modele współpracy z państwem, red. K. Ziętal, Warszawa 2016.

Ziętal K., Archiwa społeczne w Polsce - stan obecny i perspektywy, red. K. Ziętal, Warszawa 2016, s. 10-24.

Ziętal K., Archiwa społeczne w Polsce - prezentacja i analiza wyników badań, [w:] Archiwistyka społeczna. Diagnoza i wyzwania, red. E. Kołodziejska, Warszawa 2017, s. $14-32$.

\section{Strony internetowe}

$<$ https://www.archiwa.gov.pl/images/docs/Strategia_Archiwow_panstwowych_na_ lata_2010_2020.pdf/>, [dostęp 16.09.2020].

<https://www.archiwa.gov.pl//pl/dla-uzytkownikow/wydawnictwa/e-publikacje/ problemy-warto\% $\mathrm{C}_{5} \% 9$ Bciowania-dokumentacji-wsp\% $\mathrm{C}_{3} \% \mathrm{~B}_{3} \% \mathrm{C}_{5} \% 82$ czesnej. $\mathrm{pdf} />$, [dostęp 16.09.2020].

Kancelaria Sejmu Biuro Komisji Sejmowych. Pełny zapis przebiegu posiedzenia Komisji

Kultury i Środków Przekazu (nr 15) z dnia 29 lutego 2012 r. <https://www.archiwa. gov.pl/Sejmowa-Komisja-Kultury2012/Sytuacja_narodowego_zasobu_archiwalnego_i_archiwów_państwowych.pdf/>, [dostęp 16.09.2020].

$<$ https://www.archiwa.gov.pl/pl/materiay/725-slownikarchiwalny/>, [dostęp 27.04.2020]. $<$ https://www.nik.gov.pl/ochrona-zasobu-archiwalnego/NIK-P-19-024-ochrona-narodowego-zasobu-archiwalnego.pdf/>, [dostęp 24.10.2020].

$<$ http://repozytorium.umk.pl/bitstream/handle/item/Archiwistyka_dla_początkujących-Chorążyczewski_Waldemar2014.pdf/>, [dostęp 27.04.2020]. <http://orzeczenia.nsa.gov.pl/doc/122F2004E3>, [dostęp: 16.12.2020]. 